\title{
Factors influencing individual movements and behaviours of invasive European barbel Barbus barbus in a regulated river
}

\author{
Catherine Gutmann Roberts • Andrew M. Hindes • J. Robert Britton
}

Received: 26 April 2018/Revised: 13 December 2018/Accepted: 14 December 2018/Published online: 3 January 2019

(C) The Author(s) 2019

\begin{abstract}
Riverine fish are often adversely affected by impoundments that reduce longitudinal connectivity and impede movements, while river fishery performance is often enhanced by introductions of non-indigenous fishes that diversify angling opportunities. The influence of factors (including impoundment) on the movements of European barbel Barbus barbus, a fish frequently introduced for angling, was tested in the continuous reach of the lower River Teme and Severn, western England. Following capture by electric fishing and angling, the movements of 18 fish were followed for 12 months using acoustic telemetry. Weirs at the upstream end of both river reaches impeded fish movements; only three fish traversed the Teme weir and no fish traversed the Severn weir. Net movements were mainly upstream in spring and downstream in autumn, and the daily movements of fish were asynchronous between individuals. Total (home) ranges varied considerably between individuals; those of fish initially captured by angling were
\end{abstract}

Handling editor: Ingeborg Palm Helland

C. Gutmann Roberts $(\varangle)$ · A. M. Hindes · J. R. Britton Faculty of Science and Technology, Department of Life and Environmental Sciences, Bournemouth University, Poole, Dorset BH12 5BB, UK

e-mail: cgutmannroberts@bournemouth.ac.uk

\section{A. M. Hindes}

Fishtrack Ltd, Southend Farm Cottages, 2 Kings Lane, Weston, Beccles NR34 8TG, UK significantly smaller than those captured by electric fishing. This potentially relates to fish with smaller total ranges being more vulnerable to angling via higher spatial encounters. The results reveal considerable individual variation in the movement of $B$. barbus and emphasises how river regulation can impact the dispersal and behaviour of river fishes.

Keywords Acoustic telemetry · Fish movement . Non-indigenous · Weirs

\section{Introduction}

The impacts of anthropogenic activities on river ecosystems include those resulting from river engineering that reduces habitat diversity and river connectivity (Britton \& Pegg, 2011; Capra et al., 2018). The loss of habitat heterogeneity and longitudinal connectivity has considerable implications for fish communities, with the potential for loss of key habitats, including spawning gravels and off-channel nursery areas (Mouton et al., 2007; Ziv et al., 2012). These issues are frequently associated with anadromous salmonid fishes, with extensive research completed on the impacts of river engineering on their populations (e.g. Beechie et al., 1994; Buddendorf et al., 2017). It is, however, apparent that even relatively minor engineering schemes can have implications for the movements of fishes more generally 
(Lucas \& Frear, 1997; Ovidio \& Phillipart, 2002; Birnie-Gauvin et al., 2017).

Other anthropogenic impacts on river ecosystems include the manipulation of the composition of the fish community, with fish frequently introduced and stocked for the enhancement of recreational angling (Cowx, 1994; Britton et al., 2004; Bašic \& Britton, 2016). In many European rivers, hatchery-reared North American rainbow trout Oncorhynchus mykiss (Walbaum, 1792) are frequently released in large numbers for angling (Britton \& Gozlan, 2013), although most released fish are captured soon after release and removed from the system (Fausch, 2007). In contrast, the stocking of cyprinid fishes potentially has longer term ecological consequences due to their long lifespans ( $>15$ years) and their exploitation by catch-and-release angling (Bašić \& Britton, 2016). Thus, individuals can persist in the environment and potentially establish invasive populations, even after a long lag period (Crooks \& Soulé 1999; Crooks, 2005). The movements of the introduced fish in their new range and how these relate to their behaviours in their native range are then important in determining their ability to disperse, including their ability to traverse river engineering structures such as navigation weirs.

In their indigenous range, telemetry studies have revealed that European barbel Barbus barbus (Linnaeus, 1758) populations are mainly comprised of individuals that are relatively sedentary, characterised by relatively small home ranges $(<1 \mathrm{~km})$ (Britton \& Pegg, 2011). A small proportion of individuals, generally around $10 \%$ of the population, tend to be more mobile, with regular movements within a relatively large home range $(>10 \mathrm{~km})$ (Lucas \& Frear, 1997). The reasons for this individual variability in movement remain unclear (Britton \& Pegg, 2011). Given B. barbus inhabit the middle and lower reaches of European lowland rivers, their movements can potentially be heavily disrupted by engineered structures, such as weirs (Baras et al., 1994; Lucas \& Frear, 1997; Bunt, 2001; Freyhof \& Brook, 2011). Populations of non-indigenous B. barbus are also present in some European rivers, such as in Western Britain and Italy, where fish were released to enhance angling (Wheeler \& Jordan, 1990; Antognazza et al., 2016; Carosi et al., 2017). In these rivers, knowledge of their movement and behaviour is important for understanding their dispersal, such as their ability to by-pass engineering structures, and for comparing their behaviour in their indigenous versus non-indigenous range. In addition, home range size can be an important influence on the probability of angling capture in some fishes (Alós et al., 2012). Consequently, testing of movement data between tagged fish captured by angling and other methods potentially indicate how the evaluation of long-term fish behaviour can be influenced by the initial capture method.

The aim of this study was to quantify the movements and behaviours of a non-indigenous and invasive $B$. barbus population in an engineered lowland river system. The study area was the lower River Teme and Severn, western England (Fig. 1). These rivers provided a continuous riverine habitat that was potentially delimited from areas further upstream in both rivers by two weirs, with extensive river channelization also apparent in the Severn (Fig. 1). The only introduction of $B$. barbus in the basin was over 500 adult fish into the middle reaches of the River Severn in 1956 (Antognazza et al., 2016). These fish developed a sustainable population that dispersed throughout much of the basin, with anglers reporting their presence in catches in the River Teme from the 1970s (Gutmann Roberts \& Britton, 2018). The objectives were to: (1) assess the proportion of time individual fish resided in each river and how this varied according to season and environmental factors; (2) assess the influence of anthropogenic barriers on fish movements; (3) quantify the extent of individual differences in their home range size, total and net movements and (4) identify the influence of initial capture technique on the movement behaviour of individual fish. These objectives were completed through the application of acoustic telemetry over a 12 month study period. The results were evaluated in the context of $B$. barbus behaviour in their indigenous versus non-indigenous range and in relation to the influence on movements of river engineering.

\section{Materials and methods}

Study area

The study was completed between October 2015 and September 2016. The primary area of study was downstream of Powick weir on the River Teme $\left(52^{\circ} 10^{\prime} \mathrm{N},-2^{\circ} 14^{\prime} \mathrm{W}\right)$ through to its confluence with the River Severn, and then in the River Severn 

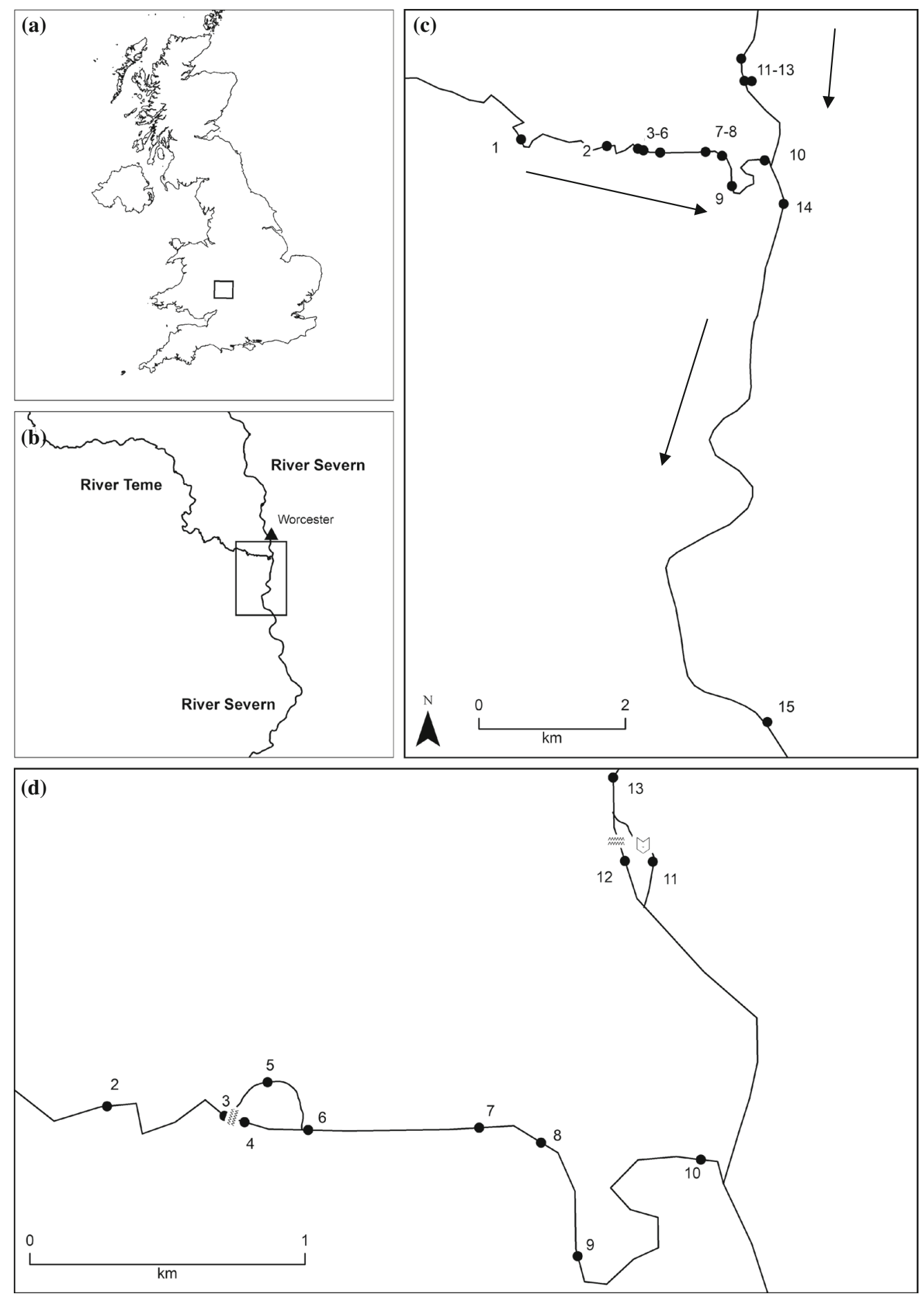

Fig. 1 Maps showing: (a) the position of the study area within the UK; (b) the study area within the River Teme and Severn; (c) the acoustic array, with the 15 receiver locations with arrows indicating direction of water flow and (d) detailing the receiver locations with barriers; weirs (man) and a lock (Y). Receiver 5 was located on the Mill leat and receivers 11 and 12 were separated by Diglis Island. All receivers were in place for 12 months of study, except (8) that was moved to (1) on 07/07/ 16 
between Diglis weir (at the upstream end of the study section) and Severn Stoke (at the downstream end) (Table 1; Fig. 1). A fixed array of 14 acoustic receivers (VR2, Vemco Ltd, Halifax, Nova Scotia, Canada) were deployed in this area, including upstream of both Powick and Diglis weirs to test whether these were passable to B. barbus. Whilst all receivers were in place for the duration of the 12 months, one receiver was re-deployed during the study period (on 07/07/16). This was Receiver 8 that was moved to above Powick weir from a downstream area, in order to measure fish movements more effectively at the upstream end of the array (Table 1; Fig. 1). The total river length within the array of acoustic receivers was $17 \mathrm{~km}$. This covered $6 \mathrm{~km}$ of river length in the River Teme and $11 \mathrm{~km}$ of river length in the River Severn (Fig. 1). As the fish were all sampled from the River Teme section of the study area, the acoustic receivers were mainly deployed in the River Teme to facilitate the collation of movement data at a relatively fine spatial scale $(n=9)$, with one receiver at the confluence of the two rivers and then the remainder in the River Severn to facilitate the collation of movement data at a wider spatial scale $(n=5)$ (Fig. 1). All receivers were placed within pools to minimise the effect of turbulence in the riffle areas from inhibiting the ability of the receivers to detect the hydroacoustic signals from the tags.

In the study area, the River Teme primarily comprised of sequences of large pools and riffles within a river channel of up to $15 \mathrm{~m}$ width and depths $<2 \mathrm{~m}$ (Harrison et al., 2017). Overhanging trees (primarily Salix spp.) were abundant in the riparian zone. In-stream macrophyte growth was minimal. The River Teme weir (Powick weir) was a $3 \mathrm{~m}$ high 'crump weir'. It had a fish pass on the left hand bank that was designed to assist the upstream passage of Atlantic salmon Salmo salar Linnaeus, 1758. The weir has also been modified with the addition of boulders to assist adult $S$. salar to pass directly over the weir. The River Severn downstream of Diglis weir was highly impounded and navigable, with heavy boat traffic in summer. With the exception of the weir pool at Diglis, depths were consistently $>4 \mathrm{~m}$, with widths generally $>30 \mathrm{~m}$. Diglis weir is a plain concrete structure that has a head-drop of $2.5 \mathrm{~m}$ at $\mathrm{Q}_{95}$ flow and no installed fish pass. A lock is located on the left hand bank for navigation purposes (Fig. 2).

Fish sampling and tagging procedures

The 22 B. barbus tagged in the study were sampled by a combination of electric fishing $(n=12)$ and rod and line angling $(n=10)$, and all were captured within the River Teme (Table 2). Electric fishing was completed from a boat, with fish captured between the weir pool at Powick (receiver 4) and downstream for approximately $1 \mathrm{~km}$ to receiver 9 (Table 1; Fig. 1). Captured fish were held in large water-filled containers before
Table 1 Receiver number (cf. Fig. 1), and location coordinates (Degrees, minutes, seconds), river and position (U/S: upstream of Powick or Diglis Weir; D/S: downstream of Weir) and location name, and the total number of detections ('Detections') from all fish in the 12 months of study

All receivers were in place for 12 months of study, except (8) that was moved to (1) on $07 / 07 / 16$

\begin{tabular}{llllr}
\hline Receiver & \multicolumn{2}{l}{ Location (Northings and Eastings) } & River position & Detections \\
\hline 1 & $52^{\circ} 10^{\prime} 15.18^{\prime \prime}$ & $-2^{\circ} 16^{\prime} 15.51^{\prime \prime}$ & Teme, U/S & 13 \\
2 & $52^{\circ} 10^{\prime} 11.86^{\prime \prime}$ & $-2^{\circ} 15^{\prime} 13.91^{\prime \prime}$ & Teme, U/S & 75 \\
3 & $52^{\circ} 10^{\prime} 11.71^{\prime \prime}$ & $-2^{\circ} 14^{\prime} 50.29^{\prime \prime}$ & Teme, U/S & 10,559 \\
4 & $52^{\circ} 10^{\prime} 10.85^{\prime \prime}$ & $-2^{\circ} 14^{\prime} 47.94^{\prime \prime}$ & Teme, D/S & 38,989 \\
5 & $52^{\circ} 10^{\prime} 15.49^{\prime \prime}$ & $-2^{\circ} 14^{\prime} 44.99^{\prime \prime}$ & Teme, D/S & 15 \\
6 & $52^{\circ} 10^{\prime} 13.37^{\prime \prime}$ & $-2^{\circ} 14^{\prime} 31.38^{\prime \prime}$ & Teme, D/S & 140,337 \\
7 & $52^{\circ} 10^{\prime} 10.02^{\prime \prime}$ & $-2^{\circ} 14^{\prime} 3.12^{\prime \prime}$ & Teme, D/S & 25,945 \\
8 & $52^{\circ} 10^{\prime} 7.56^{\prime \prime}$ & $-2^{\circ} 13^{\prime} 49.17^{\prime \prime}$ & Teme, D/S & 31,892 \\
9 & $52^{\circ} 9^{\prime} 54.22^{\prime \prime}$ & $-2^{\circ} 13^{\prime} 41.88^{\prime \prime}$ & Teme, D/S & 470761 \\
10 & $52^{\circ} 10^{\prime} 6.06^{\prime \prime}$ & $-2^{\circ} 13^{\prime} 19.63^{\prime \prime}$ & Confluence & 86,044 \\
11 & $52^{\circ} 10^{\prime} 39.94^{\prime \prime}$ & $-2^{\circ} 13^{\prime} 29.03^{\prime \prime}$ & Severn, D/S & 1489 \\
12 & $52^{\circ} 10^{\prime} 40.33^{\prime \prime}$ & $-2^{\circ} 13^{\prime} 32.48^{\prime \prime}$ & Severn, D/S & 4391 \\
13 & $52^{\circ} 10^{\prime} 51.23^{\prime \prime}$ & $-2^{\circ} 13^{\prime} 26.88^{\prime \prime}$ & Severn, U/S & 0 \\
14 & $52^{\circ} 9^{\prime} 45.68^{\prime \prime}$ & $-2^{\circ} 13^{\prime} 3.58^{\prime \prime}$ & Severn, D/S & 4724 \\
15 & $52^{\circ} 5^{\prime} 56.62^{\prime \prime}$ & $-2^{\circ} 13^{\prime} 22.87^{\prime \prime}$ & Severn, D/S & 62 \\
\hline
\end{tabular}




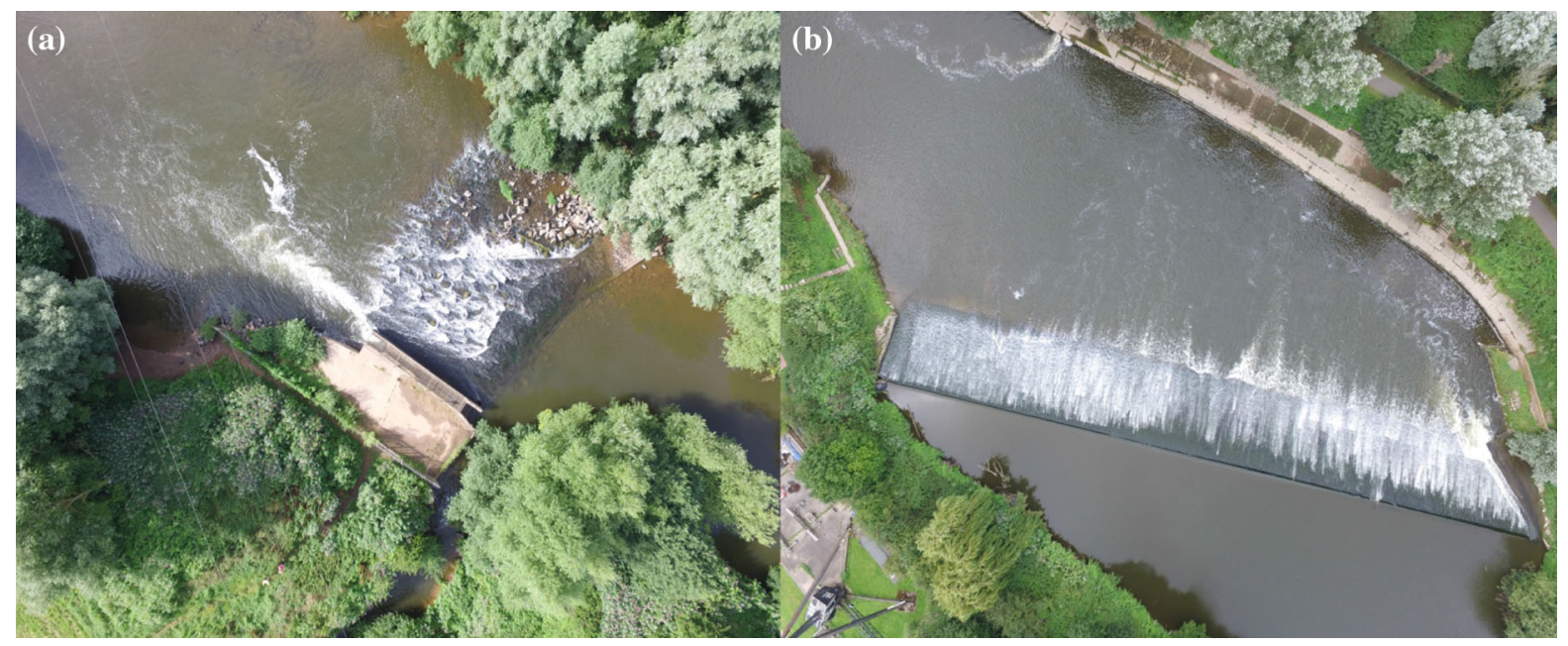

Fig. 2 Aerial images taken from a drone in 2016, of a Powick weir, located between receivers 3 and 4 in the River Teme, and b Diglis weir, located between receivers 12 and 13 in the River

being transferred to aerated holding tanks prior to tagging. Fish captured by angling were generally caught in the same area as the electric fishing; where fish were captured further downstream, they were always from areas at least $1 \mathrm{~km}$ upstream from the River Severn confluence. These fish were initially held in fish keep sacks before also being transferred to aerated holding tanks prior for preliminary condition assessment prior to tagging. All fish were caught and tagged on 22/09/15 and 23/09/15.

Each fish was tagged with a Vemco V9 acoustic transmitter (hereafter referred to as 'acoustic tags'), with each tag being $9 \times 45 \mathrm{~mm}$ and approximate weight $3 \mathrm{~g}$, and operated on $69 \mathrm{kHz}$ (Vemco, 2017). The tags were coded to allow individual fish identification and were set to pulse randomly once every 60 to $180 \mathrm{~s}$, providing a battery life of each tag of approximately 22 months. Random repeat pulse rates allowed multiple individual $B$. barbus to be monitored simultaneously within a given area and without continuous signal overlap and risk of signal interference at the receivers. Upon reception of a signal from a V9 tag, the VR2 receivers identified the tag number by its unique coded transmission pattern and recorded its time of detection. Range testing revealed that detection distances for V9 transmitters were generally $70 \mathrm{~m}$ in the River Teme and $100 \mathrm{~m}$ in the River Severn; in subsequent analyses, a standard detection distance of $100 \mathrm{~m}$ was thus utilised for subsequent movement analyses. Detection distances exceeded the width of
Severn, that in entirety present the two potential barriers to upstream movement in the study area

the rivers in both cases, allowing the receivers to function as a gated array. The river bed slope in the study area was measured at four sites downstream of the weir at Powick, which ranged between -1.35 to $0.35 \%$ (as measured with Leica dumpy in October 2015) and was assumed not to have limited the power of receivers to detect tagged fish.

Insertion of the V9 tag was into the peritoneal cavity; the mid-ventral incision was closed with a single suture and application of surgical adhesive. Throughout this procedure, the fish were always under general anaesthesia (tricaine methanesulfonate; MS222). They were then transferred to recovery tanks with fresh river water, where they were held until their return to normal swimming behaviour. All fish were then returned to the river within $500 \mathrm{~m}$ of their capture site. Additional information recorded for each fish was fork length (nearest $\mathrm{mm}$ ) and method of capture (electric fishing/angling). All surgical procedures were completed following ethical approval, were licensed under UK legislation for animal research (project licence number: PPL 70/8063) and were undertaken by a licensed, competent and experienced practitioner.

Following the return of the fish to the river, all VR2 receivers were downloaded several times to check battery life and that fish were being detected, before a final download at the end of the study period (30/09/ 16) that completed the movement dataset. All of the receivers remained operable in the study period and 


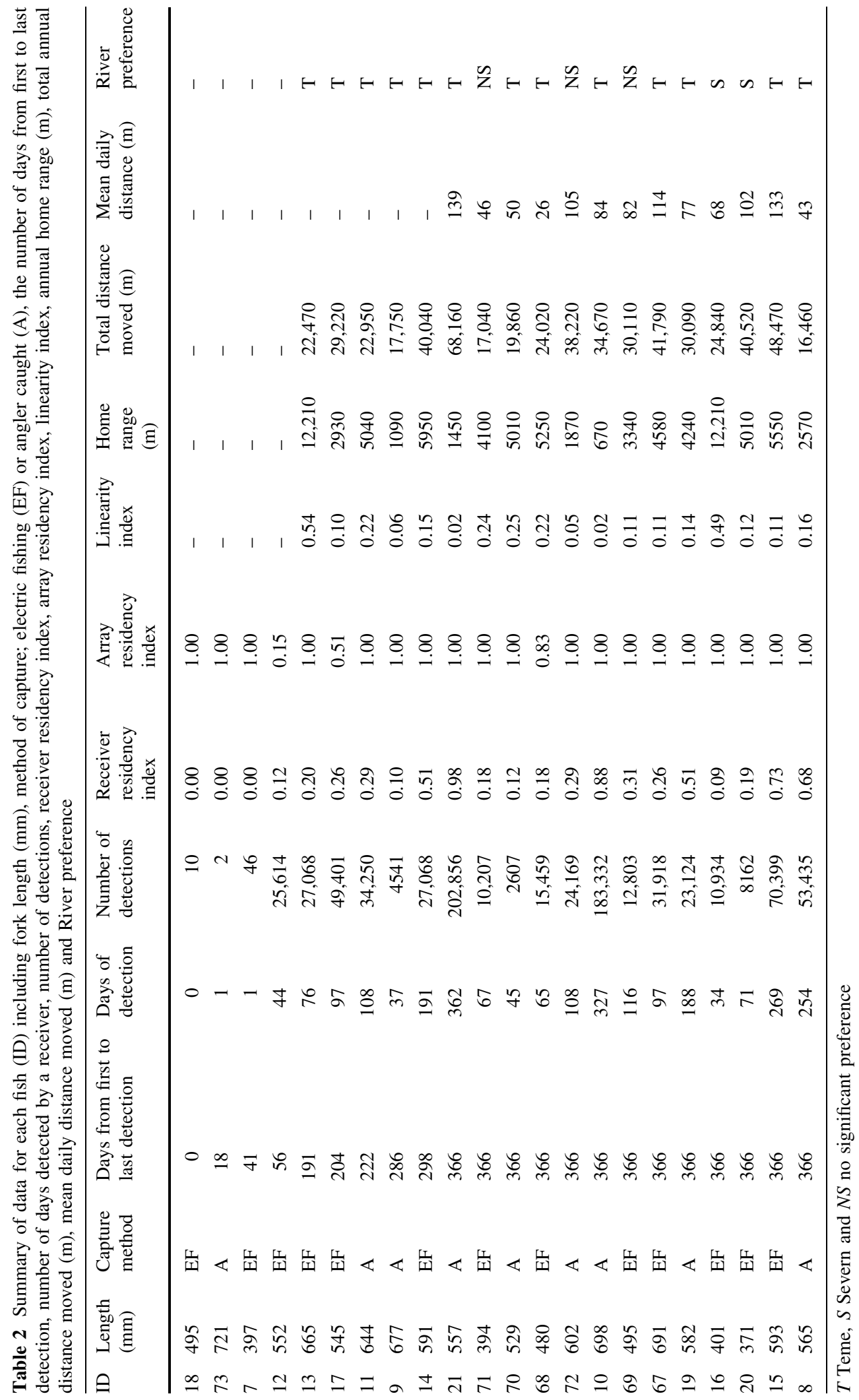


none were lost. A temperature logger (Tinytag) was deployed in each river, with recording of temperature (to $0.1^{\circ} \mathrm{C}$ ) every $3 \mathrm{~h}$. Flow data $\left(\mathrm{m}^{3} \mathrm{~s}^{-1}\right)$ were available for both rivers from the flow gauging stations operated by the Environment Agency. Flow data for the River Teme were available from the Knightwick flow monitoring station, approximately $6 \mathrm{~km}$ upstream of Powick weir $\left(52^{\circ} 10^{\prime} \mathrm{N},-2^{\circ} 14^{\prime} \mathrm{W}\right)$, and the River Severn from the Saxons Lode station $\left(51^{\circ} 59^{\prime} \mathrm{N},-2^{\circ} 10^{\prime} \mathrm{W}\right)$, located within the study area. However, where flow was used to test fish movement data, it utilised the River Teme data, given fish primarily utilised this section of the river ( $c f$. see "Results" section).

Data and statistical analyses

The influence of environmental conditions on movement patterns in the tagged fish utilised water temperature and flow data. For testing of daily fish movements, flow was used as a continuous and categorical variable. Where it was used categorically, three groups were used: flows exceeding $Q_{10}$, flows between $\mathrm{Q}_{10}$ and $\mathrm{Q}_{50}$ and flows less than $\mathrm{Q}_{50}$, where these values were taken from a long-term dataset (Centre for Ecology \& Hydrology, 2017). The rationale for this grouping was to quantify movements in relation to very high, high or median flows, where the flow categories related to the long-term flow regime of the river.

For water temperature, the data collated from the data loggers were used to calculate daily means. The water temperature data were then used in two ways: as continuous data and as categorical data in three groups ( $\leq 10^{\circ} \mathrm{C}, 10.1$ to $15^{\circ} \mathrm{C}$ and $\geq 15.1^{\circ} \mathrm{C}$ ). These groups were chosen as the behaviour of $B$. barbus varies above and below a temperature threshold of $10^{\circ} \mathrm{C}$ (Baras, 1995a). There was only a single day during the study period below the reported thermal limit of $B$. barbus activity $\left(4^{\circ} \mathrm{C}\right.$; Baras, $\left.1995 \mathrm{~b}\right)$ and so a separate temperature class was not included for this. When grouped, the number of days in each temperature group was $161\left(\leq 10^{\circ} \mathrm{C}\right), 91\left(10.1\right.$ to $\left.15^{\circ} \mathrm{C}\right)$ and 114 $\left(\geq 15.1^{\circ} \mathrm{C}\right.$ ). As water temperatures between the two rivers were significantly and positively related with linear regression $\left(R^{2}=1.00, \quad F_{1,365}=4.06 \times \mathrm{e}^{21}\right.$; $P<0.01$ ), only water temperature from the River Teme were used in analyses.
Analyses of fish movements were completed for the period of $01 / 10 / 15$ to $31 / 09 / 16(n=366$ days due to leap year). The initial days of movement between tagging and 30/09/15 were not utilised. This avoided analysis of initial post-tagging behaviours, when fish removed from a specific area were displaced by their return to the river in a slightly different area (i.e. they potentially undertook an enforced movement; Mitamura et al., 2012). Utilising the fish movement data from all receivers (all expressed in terms of river length (m) moved), the data for each individual fish were initially manipulated within the software 'Vtrack' (Campbell et al., 2012), a package written within the R-programming language (R Core Team, 2017), prior to being analysed for a series of relevant movement metrics.

The equations used for calculating all the movement indices and parameters are provided in Table 3. For indices of the extent of the residence of each fish in the receiver array, the residency index and the linearity index were calculated (Eqs. 1 and 2; Acolas et al., 2017). To overcome the issues that a tagged fish could be within the receiver array on a given day but were not necessarily detected on a VR2 receiver, a further index was calculated, 'residency within the array' (Eq. 3). The VR2 receivers located in both the Teme and the Severn meant that the duration of residency of individual fish in each river was determined separately (rounded to the nearest day). This enabled the extent of residency in each river to be determined for the study period (Eq. 4; Table 3). This residency was initially recorded as the number of days in each river across the study period. It was calculated by season, where the data were split into a non-spawning period $(01 / 10 / 15$ to $29 / 02 / 16$; $01 / 09 / 16$ to $30 / 09 / 16$; i.e. covering the autumn and winter period) and a spawning period (01/ $03 / 16$ to $30 / 08 / 16$; i.e. covering the spring and summer period). Note the spawning season can be prolonged in $B$. barbus and was inferred from larval and juvenile samples collected in summer 2016 (Gutmann Roberts $\&$ Britton, 2018). The extent of river residence was then tested between the three water temperature data groupings, as water temperature can have a substantial effect on B. barbus movements (Baras, 1995a). In both cases, paired sample $t$ tests were used, with testing of the significance of the difference in the proportional number of days spent in the Teme and Severn from $1: 1$. 
Table 3 The movement variables and indices, and equation number, that were calculated for the Barbus barbus movement data

\begin{tabular}{|c|c|c|}
\hline Equation number & Parameter & Equation/explanation \\
\hline 1 & Residency Index & $\frac{\text { Number of days detected by at least one receiver }}{\text { Total number of days of study }}$ \\
\hline 2 & Linearity Index & $\frac{\text { Total range }}{\text { Total movement }}$ \\
\hline 3 & $\begin{array}{l}\text { Residency within the } \\
\text { array }\end{array}$ & $\frac{\text { Number of days that the fish was in the array (determined by detections at limits) }}{\text { Total number of days of the study (366) }}$ \\
\hline 4 & River residency & Number of days detected in either the Teme or Severn during the study \\
\hline 5 & Total (home) range $(\mathrm{m})$ & $\begin{array}{l}\text { (Length of river between receivers with detections in the Teme) } \\
+(\text { Length of river between receivers in the Severn) }\end{array}$ \\
\hline 6 & Total movement $(\mathrm{m})$ & Sum of all upstream and downstream movements \\
\hline 7 & Daily movement (m) & Total distance moved by an individual fish on a given day \\
\hline 8 & Net movement $(\mathrm{m})$ & Total distance moved upstream - Total distance moved downstream \\
\hline
\end{tabular}

The movement of $B$. barbus in the rivers was potentially limited in an upstream direction by the weirs (Fig. 1). Consequently, the movement data for each individual fish were analysed to determine the number of movements into each weir pool and whether the fish then traversed the weir (as detected by the VR2 receivers upstream). In the River Teme, a successful ascent of Powick weir was defined as when the ascending fish was detected at both the initial upstream receiver and then next one upstream $(680 \mathrm{~m})$. This was due to the weir being flooded out at very high water levels, resulting in individual fish being detected simultaneously on the receivers up- and downstream of the weir. However, under the majority of flow conditions, this simultaneous detection of fish on the receivers up- and downstream of the weir did not occur due to the water turbulence and/or the height of the weir preventing the upstream receiver from detecting a downstream fish.

To determine the length of river each fish utilised, total range was calculated as a proxy of home range size, and was taken as the length of river between the furthest upstream and furthest downstream detections (Eq. 5; Table 3). Where this covered both rivers, it was taken the sum of the two distances (Eq. 5). It was tested against fish length (linear regression) and fish capture method (i.e. electric fishing vs. angling; ANOVA). It was then split between the 'spawning' (01/03/16 to $30 / 08 / 16)$ and 'non-spawning season' (01/10/15 to $29 / 02 / 16$ and $01 / 09 / 16$ to $30 / 09 / 16)$, with linear regression testing the relationship between season and total range. Total movement represented the total distance moved by each fish, irrespective of whether it moved up- or downstream, and so indicated their total activity (Eq. 6; Table 3). The distance between the VR2 receivers was determined as the river length $(\mathrm{m})$ to the nearest $100 \mathrm{~m}$ (as increased accuracy was restricted by detection range). Initial testing of total movement was as per total range. A Generalized Linear Mixed model (GLM) then tested the effects of flow and temperature on total movement by month, with individual fish used as a random factor, using the package glmm (Knudson, 2017) in R (R Core Team, 2017). Only fish with a full 12 months of movement data were used in the test to reduce false zeros in the dataset ( $n=13$; Table 2). This model also accounted for the interaction between flow and temperature, and it used a Poisson distribution, as it was the best fit of the distribution of the response data.

For daily movement (Eq. 7; Table 3), only fish with a full 366 days from first to last detection were included in analyses ( $n=13$; Table 2$)$. As each day of movement could not be treated as being independent to the movement on the following or previous day, then the movement $(\mathrm{m})$ and environmental (temperature and flow) time-series data were tested for temporal autocorrelation using a Box-Pierce test, from package 'tseries' (Trapletti et al., 2017), where the test results were reported as $\chi^{2}$ values and their significance. Correlation between individual daily movement time series and both environmental time-series were then tested for with cross-correlation function (ccf) estimation from the package 'tseries', which also accounts for the possibility of time-lagged effects (Trapletti et al., 2017). 'Net movement' referred to the specific distance $(\mathrm{m}$; nearest $100 \mathrm{~m})$ of the net 
difference between movement in an upstream and downstream direction (Eq. 8; Table 3). Net movement per month was tested for differences using an ANOVA and post-hoc Tukey test.

Throughout the results, where error is expressed around the mean, it represents $95 \%$ confidence intervals.

\section{Results}

Tracking data and river residency

The mean number of detections per fish was $37,155 \pm 22,483$, ranging from 2 to 202,856 (Table 2). The 22 tagged fish were detected for a total of 5956 days, of which 18 were detected regularly (days $>50, n=5838$ days). The 18 fish had a mean 'array residency index' of 0.96 , so primarily remained within the receiver array during the study period (Table 2). The 'residency index' ranged from 0.00 to 0.98 (mean $0.31 \pm 0.12$ ), with a minimum residency index of 0.12 for the 18 regularly detected fish. Only one fish had a linearity index greater than 0.50 (Table 2). The short detection period of four fish (ID 7, 12, 18 and 73) meant their data were omitted from subsequent analyses (Table 2). For monthly and daily analyses, a further five fish with less than 366 days from first to last detection were omitted.

Of the 5838 detection days for the 18 analysed fish, they were detected for 4490 days on the River Teme

Table 4 Environmental conditions under which tagged fish were detected as being within the Powick weir pool $(W)$ for more than one detection or on the date of ascending Powick receivers and 1348 days on the Severn receivers (Table 1). There was a marginally significant effect between the number of days that fish were detected in either river between spawning and non-spawning periods (Teme: $t_{17}=-1.99, \quad P=0.06 ; \quad$ Severn: $\left.t_{13}=-2.04, P=0.06\right)$. The tagged fish were always detected on significantly more days in the Teme than the Severn at $>10.1^{\circ} \mathrm{C}$, but with no overall river residence at $<10.1^{\circ} \mathrm{C}$ (paired $t$ tests: $\leq 10^{\circ} \mathrm{C}$ : $t_{17}=1.71, \quad P=0.11 ; \quad 10.1-15.0^{\circ} \mathrm{C}: \quad t_{17}=5.93$, $\left.P<0.01 ; \geq 15.1^{\circ} \mathrm{C}: t_{17}=6.38, P<0.01\right)$.

\section{Barriers to movement}

During the study period, six tagged B. barbus approached Powick weir and three ascended it, and five tagged fish approached Diglis weir and none ascended it. Successful ascensions at Powick weir only occurred during March and April 2016, and when flows exceeded $\mathrm{Q}_{50}$ (Table 4) and water temperatures ranged between 6.8 and $10.1^{\circ} \mathrm{C}$ (Table 4). The times of day of when the fish ascended were 09:30, 15:25 and 00:03. Of the three ascended fish, only one fish returned back downstream of the weir during the period of the study (after 62 days, 16th June 2016).

Total (home) range

Mean total range size of the 18 fish was $4600 \pm 1500 \mathrm{~m}$ (range: 700 to $12,200 \mathrm{~m}$; Table 2). The relationship between fish length and total range

weir $(A)$ and then month during which the fish was present there, denoted by the first three letters

\begin{tabular}{|c|c|c|c|c|c|c|c|c|c|c|c|}
\hline \multirow[t]{3}{*}{ Fish ID } & \multicolumn{4}{|c|}{ Water flow $\left(\mathrm{m}^{3} \mathrm{~s}^{-1}\right)$} & \multicolumn{4}{|c|}{ Water temperature $\left({ }^{\circ} \mathrm{C}\right)$} & \multirow[t]{3}{*}{ Days } & \multicolumn{2}{|l|}{ Months } \\
\hline & \multicolumn{3}{|l|}{$W$} & \multirow[t]{2}{*}{$A$} & \multicolumn{3}{|l|}{$W$} & \multirow[t]{2}{*}{$A$} & & \multirow[t]{2}{*}{$W$} & \multirow[t]{2}{*}{$A$} \\
\hline & Min & Mean & $\operatorname{Max}$ & & Min & Mean & $\operatorname{Max}$ & & & & \\
\hline 71 & 6.5 & 15 & 36.5 & - & 10.7 & 17.4 & 21.2 & - & 25 & Jun, Jul, Aug & - \\
\hline 15 & 46.8 & 120.3 & 175.4 & - & 7.4 & 8.6 & 10.1 & - & 3 & Dec, Jan & - \\
\hline 14 & 138.7 & 153.9 & 169.1 & - & 7.4 & 7.7 & 8.0 & - & 2 & Jan & - \\
\hline 68 & 46.4 & 46.4 & 46.4 & 46.4 & 10.1 & 10.1 & 10.1 & 10.1 & 1 & Apr & April \\
\hline 67 & 51.5 & 109.7 & 165.9 & 54.3 & 4.6 & 5.9 & 7.4 & 9.3 & 13 & Jan, Feb, Apr & April \\
\hline 17 & 33.3 & 95.4 & 180.5 & 102.8 & 4.6 & 7.0 & 10.2 & 6.8 & 43 & Dec, Jan, Feb, Mar & March \\
\hline
\end{tabular}

Only fish ID in bold ascended the weir 
Fig. 3 a Mean total movement (m) of B. barbus $(n=18)$ between nonspawning and spawning seasons with $95 \%$

confidence intervals and significant linear regression (dotted line; $R^{2}=0.27$, $\left.F_{1,17}=5.98, P=0.03\right)$. b Monthly total movements (m) of B. barbus $(n=13$, filled circle, solid line) with 95\% confidence intervals on primary axis and mean water temperature $\left({ }^{\circ} \mathrm{C}\right.$, filled diamond, long dashed line) and mean water flow $\left(\mathrm{ms}^{-3}\right.$, filled triangle, dashed line) on the secondary axis
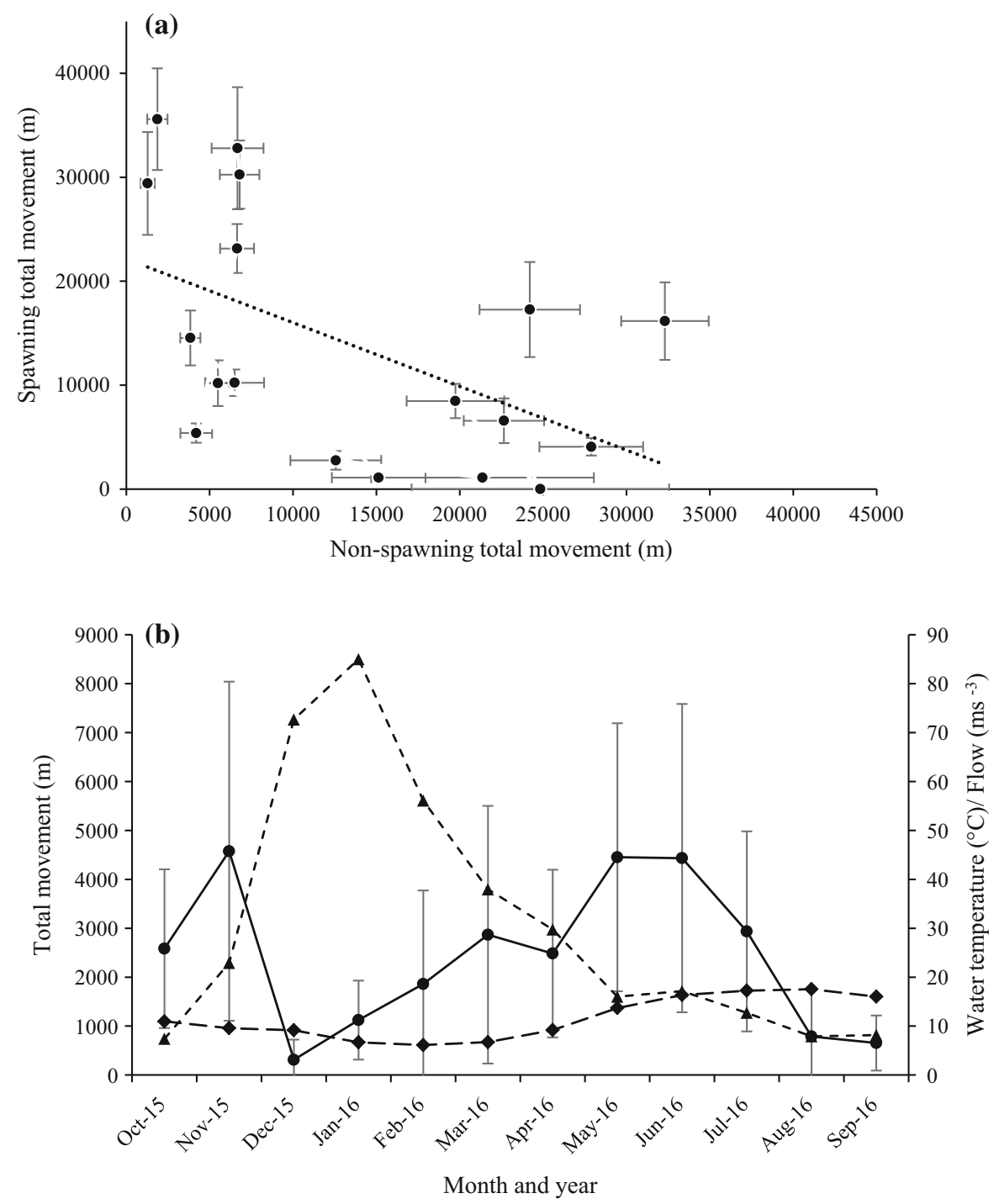

size was not significant $\left(R^{2}=0.04, F_{1,21}=0.90\right.$, $P=0.35$ ). There was, however, a significant difference between the total range size of the tagged barbel that were sampled by electric fishing ( $n=10$; mean $6112 \pm 2075 \mathrm{~m})$ and by angling $(n=8$; mean $2739 \pm 1229 \mathrm{~m}) \quad(t$ test: $t=-2.742 ; \quad P=0.02)$. Across the 18 fish, the mean total distance moved during the tracking period was $27,327 \pm 4919 \mathrm{~m}$ (range 16,460-48,470 m) (Table 2). The relationship between body length and total distance moved was not significant $\quad\left(R^{2}=0.012, \quad F_{1,17}=0.19, \quad P=0.67\right)$. There was a weak significant negative relationship between total movement in the non-spawning versus spawning season (linear regression: $R^{2}=0.27$, $F_{1,17}=5.98, P=0.03$ ), with fish that moved less outside of the spawning season moving significantly more during it (Fig. 3a).

Total and daily movements

Mean movements of fish per month differed significantly (Table 4), with peak movements in November, May and June (Fig. 3b, 4). Individual fish had significantly different total monthly movement patterns to each other (Table 4; Fig. 5). Both flow and temperature had a significant negative effect on total movement, with months of high flow (e.g. December to February) having relatively low fish movements, and months with high temperature (e.g. July and August) having relatively low movements (Fig. 3b). 
Fig. 4 a Monthly net movements (upstream/downstream, m) of $B$. barbus $(n=13)$, filled circle, solid line) over a year with $95 \%$ confidence intervals on primary axis and mean water temperature $\left({ }^{\circ} \mathrm{C}\right.$, filled diamond, long dashed line) and mean water flow $\left(\mathrm{ms}^{-3}\right.$, filled triangle, dashed line) on the secondary axis. b Net movement of B. barbus ( $n=18$ ) by spawning (clear) and non-spawning (grey) season

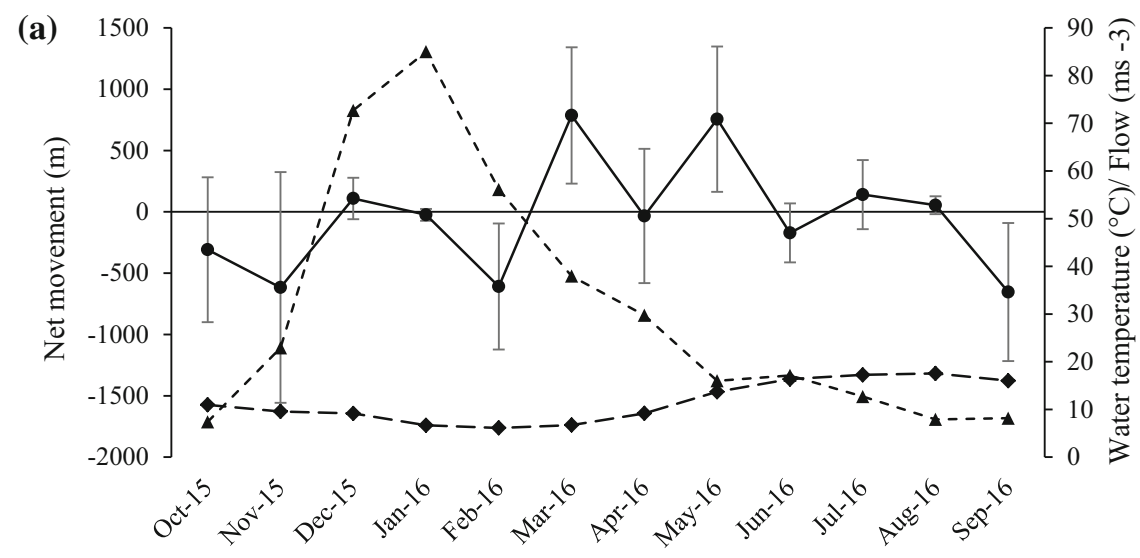

Month and Year

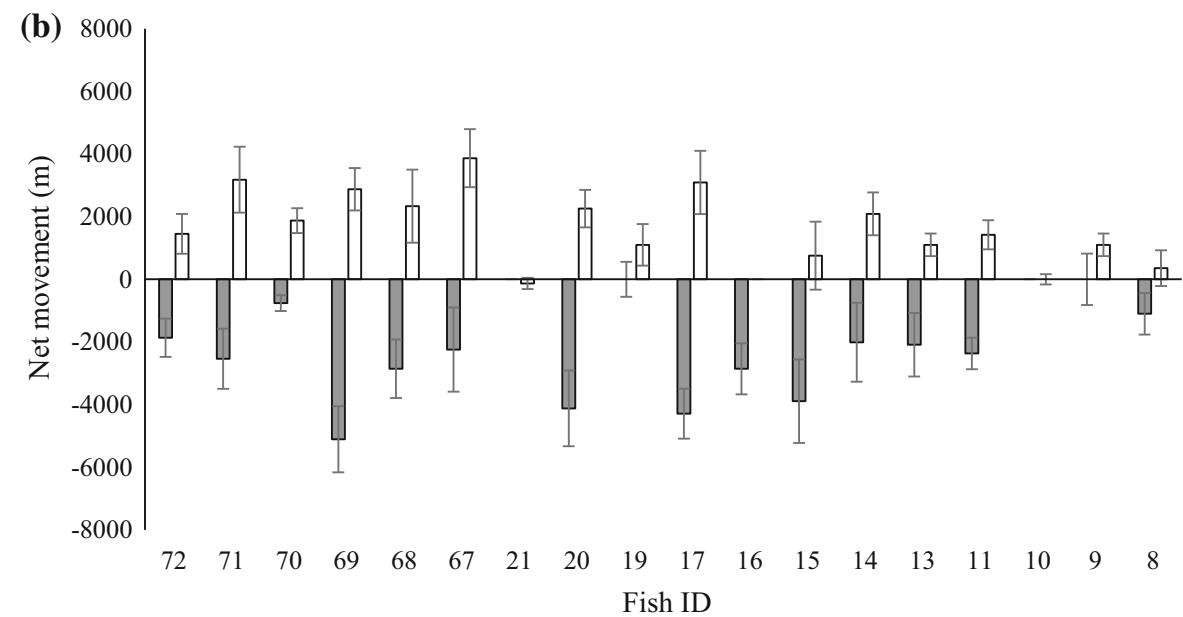

There was also a significant interaction effect of flow and temperature (Table 5), hence total movement was low when flow was low and temperature high (Fig. 3b). There was a marginally significant difference between the total movement of the tagged barbel that were sampled by electric fishing $(n=10$; mean $31,850 \pm 6350 \mathrm{~m})$ and by angling $(n=8$; mean $31,020 \pm 11,780 \mathrm{~m})\left(t\right.$ test: $\left.t_{14.2}=2.017 ; P=0.06\right)$.

Across the 13 fish with 366 days from their first to last detection, total daily movements (hereafter, 'daily movements') ranged between 0 and $1311 \mathrm{~m}$ (Table 2). Time series analysis revealed that the daily movements of individual fish were not significantly autocorrelated, suggesting fish were moving independently from each other with no synchronicity, as also supported by their low values of the linearity index (Table 2). Eight out of 13 fish had significant temporal autocorrelation, suggesting that movement had underlying correlations with time for most fish (Table 6). Most fish had daily movements that significantly correlated with flow $(n=10)$, generally a negative relationship, and temperature, but with 5 having a negative relationship and 6 having a positive relationship (Table 6).

Net movement was significantly different between months for the 18 fish (ANOVA: $F_{11}, 215=5.47$, $P<0.01$, Fig. 4a). Tukey post hoc analysis revealed the most significant upstream movements were in March and then May, with a mean upstream movement of $978 \pm 497 \mathrm{~m}$ and $546 \pm 453 \mathrm{~m}$ respectively ( $P<0.05$ from other months). The greatest downstream movements were made during February and November (Fig. 4a), with mean downstream movement of $690 \pm 464 \mathrm{~m}$ and $634 \pm 780 \mathrm{~m}$ respectively. 
When data were split into spawning and non-spawning seasons, they were significantly different (paired $t$ test: $\left.t_{17}=-6.45, P<0.001\right)$, with mean upstream movement $1595 \pm 590$ (95\% ci) $\mathrm{m}$ in the spawning season and mean downstream movement of $2116 \pm 791 \mathrm{~m}$ in the non-spawning season (Fig. 4b).

\section{Discussion}

Acoustic telemetry revealed the movements and behaviours of $18 \mathrm{~B}$. barbus in two rivers in their non-indigenous range in Western England across a 12 month period. Analyses indicated that although there were some synchronous patterns in aspects of their movements, they were highly asynchronous in others. With the two rivers providing contrasting habitat typologies, 13 of the tagged fish were primarily resident in the faster and shallower River Teme, being detected significantly more often in this river than in the impounded River Severn. This might relate to their preference for the habitats provided by the Teme, such as the pool/riffle sequences and substantial overhanging riparian vegetation (Harrison et al., 2017). However, as all the tagged fish were initially captured from the Teme, this apparent preference might also relate to their area of capture being within a core part of their total range. This pattern might thus have differed had fish been also captured and tagged from within the Severn.

The influence of the weirs at the upstream ends of the study area on B. barbus movements was marked. Three of six individuals that approached Powick weir successfully traversed, but only during high flow events. No fish traversed Diglis weir, despite five individuals approaching it. Other studies have indicated that even relatively minor obstructions can inhibit the movement of $B$. barbus (Ovidio \& Philippart, 2002). For example, in the River Nidd, Northeast England, whilst spawning movements of up $20 \mathrm{~km}$
Fig. 5 Daily net movements (m) of six individual Barbus barbus with over 366 days from first to last detection. The label of each plot is the identification (ID) number of the fish used in Table 2. Note the differences in scale on the $y$-axis

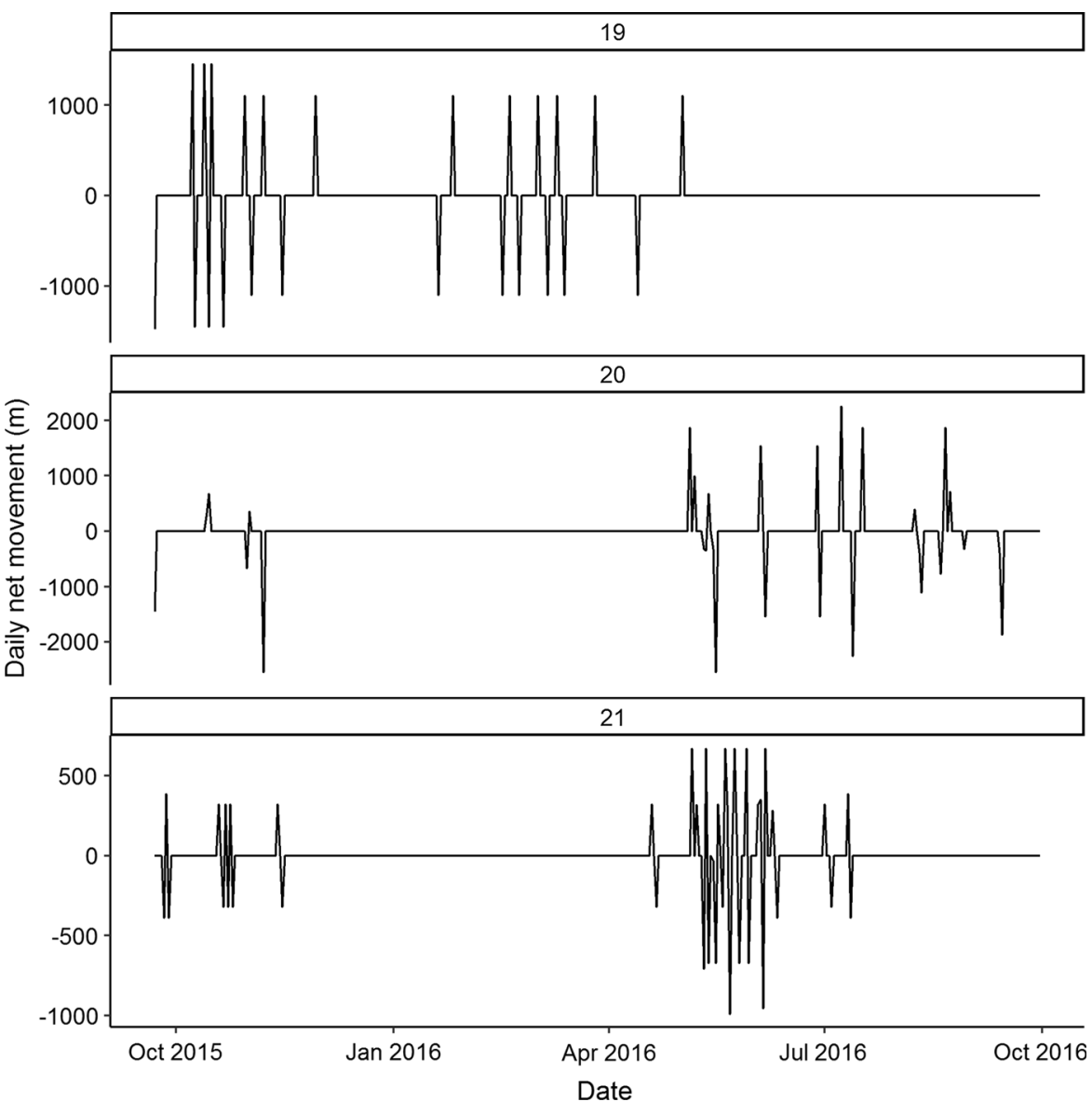


Fig. 5 continued

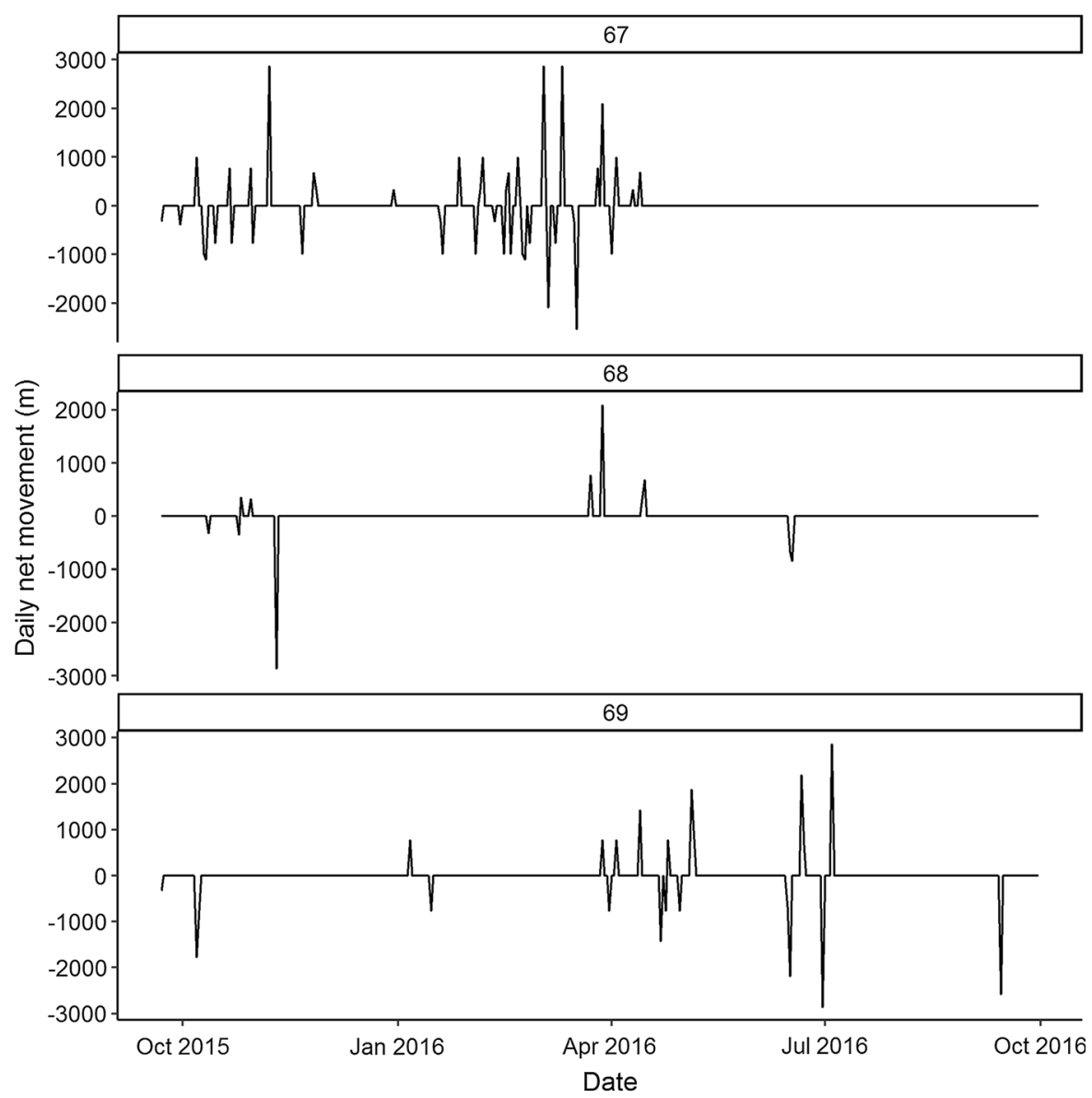

Table 5 Generalized linear mixed model results for monthly total movement, with individual fish as random effects

\begin{tabular}{lrrrr}
\hline & Estimate & SE & $z$ value & \multicolumn{1}{l}{$P$} \\
\hline Intercept & 10.82 & 0.03 & 432.20 & $<0.001$ \\
Month & -0.09 & 0.00 & -149.50 & $<0.001$ \\
Flow & -0.09 & 0.00 & -226.20 & $<0.001$ \\
Temperature & -10.86 & 0.00 & -201.60 & $<0.001$ \\
Flow: temperature & 0.01 & 0.00 & 177.70 & $<0.001$ \\
Fish ID (random) & 0.20 & 0.08 & 2.60 & 0.005 \\
\hline
\end{tabular}

occurred, of $15 \mathrm{~B}$. barbus (of 23 tagged) that approached a flow gauging weir, only six successfully traversed it (Lucas \& Frear, 1997). These six individuals then moved substantial distances upstream to spawn, probably due to the impounded water immediately upstream of the weir providing sub-optimal habitat for rheophiles such as B. barbus (Birnie-
Gauvin et al., 2017); those that did not traverse the weir moved back downstream (Lucas \& Frear, 1997). In the River Meuse, Belgium, individuals that attempted to migrate into spawning tributaries were prevented from entering due to the presence of even relatively minor physical obstacles that inhibited their upstream movement (Ovidio \& Philippart, 2002). A small proportion of individuals often do manage to successfully traverse these structures, with this usually coincident with episodes of elevated discharge (Lucas, 2000; Vilizzi et al., 2006). The results here on the movements of B. barbus in relation to Powick and Diglis weirs in the study area were consistent with these studies. Both weirs generally impeded the movements of these non-indigenous B. barbus, especially in pre-spawning, early spring period as the fish naturally start to move upstream. This blockage to their movement suggested both weirs resulted in individual B. barbus being restricted in their spawning habitat choice, generally to areas within $1 \mathrm{~km}$ of 
Table 6 Summary of autocorrelation tests between daily total movement time series for 13 Barbus barbus over 1 year and whether those fish movements were crosscorrelated with environmental factors; flow and temperature

\begin{tabular}{lllc}
\hline Fish ID & Temporally auto-correlated & Correlated with flow & Correlated with temperature \\
\hline 08 & $\chi^{2}<0.01$ & -0.04 & -0.05 \\
10 & $\chi^{2}=104.09^{*}$ & $-0.16^{*}$ & $0.32^{*}$ \\
15 & $\chi^{2}=5.35^{*}$ & $-0.01^{*}$ & $-0.25^{*}$ \\
16 & $\chi^{2}<0.01$ & $-0.02^{*}$ & $-0.11^{*}$ \\
19 & $\chi^{2}=1.48$ & $-0.06^{*}$ & $-0.15^{*}$ \\
20 & $\chi^{2}=13.43^{*}$ & $-0.13^{*}$ & $0.21^{*}$ \\
21 & $\chi^{2}=127.42^{*}$ & $-0.15^{*}$ & $0.22^{*}$ \\
67 & $\chi^{2}=0.25$ & $0.01^{*}$ & $-0.24^{*}$ \\
68 & $\chi^{2}=0.71$ & 0.04 & -0.04 \\
69 & $\chi^{2}=5.08^{*}$ & $-0.01^{*}$ & $0.05^{*}$ \\
70 & $\chi^{2}=22.98^{*}$ & -0.02 & $-0.09^{*}$ \\
71 & $\chi^{2}=24.92^{*}$ & $-0.08^{*}$ & $0.07^{*}$ \\
72 & $\chi^{2}=90.04^{*}$ & $-0.07^{*}$ & $0.17^{*}$ \\
\hline
\end{tabular}

$* P<0.05$

Powick weir (personal observations). Whilst the implications of this restricted spawning habitat were unable to be explored further here, it did mean that spawning B. barbus were frequently utilising the same spawning gravels as Squalius cephalus (Linaeus 1758), Petromyzon marinus Linnaeus, 1758 and Alosa fallax (Lacépède, 1758) (Pinder et al., 2016).

In their indigenous range, the general movement behaviour of $B$. barbus tends to involve cyclical migration patterns through the year, with movements downstream in autumn and upstream in spring and early summer (Lucas \& Batley, 1996; Lucas \& Frear, 1997). The downstream movements are often associated with flood events and upstream movement for spawning (Lucas, 2000). Post-spawning, individuals often display strong homing behaviours (Baras, 1996; Lucas \& Batley, 1996; Ovidio et al., 2007). These patterns were generally evident with the non-indigenous $B$. barbus of this study; net movements were primarily upstream from March to May, there was minimal net movement in June to August, and then net movements in winter were primarily downstream. Given that the availability of spawning gravels was limited in the study reach due to impoundment, the upstream movement of the fish in the pre-spawning period were assumed to relate to their attempts to locate suitable spawning areas (Baras \& Cherry, 1990).

A common feature of B. barbus populations is considerable intra-population differences in movement distances and home ranges (Baras, 1997). This has resulted in their populations being described as comprising of 'resident' and 'mobile' fish (Hunt and Jones, 1974; Penaz et al., 2002; Britton \& Pegg, 2011) and has been found in other freshwater fish (Radinger \& Wolter, 2014). For example, in a study on the middle River Severn in the 1970s, $86 \%$ of tagged fish were recaptured within $5 \mathrm{~km}$ of their point of release (Hunt \& Jones, 1974). However, the other fish moved more widely, with some recorded up to $34 \mathrm{~km}$ from the tagging area and the total area covered by mobile fish being $54 \mathrm{~km}$. In the River Jihlava, Czech Republic, resident fish had ranges of 250 to $780 \mathrm{~m}$ versus movements of mobile fish of up to $1680 \mathrm{~m}$ downstream and $2020 \mathrm{~m}$ upstream (Penaz et al., 2002). Elsewhere, home ranges of up to $2200 \mathrm{~m}$ have been recorded (Baras \& Philippart, 1989; Pelz \& Kästle, 1989; Baras \& Cherry, 1990; Baras, 1997). These studies indicate considerable differences in home range sizes between rivers and between individuals in the same river, with Lucas \& Baras (2001) revealing a continuum of annual individual movements of B. barbus from $<1$ to $>30 \mathrm{~km}$. Consequently, the mean total range size of the 18 tracked fish of this study of $4600 \pm 1500 \mathrm{~m}$, with a range of 700 to $12,200 \mathrm{~km}$, is relatively typical for the species. Moreover, the total ranges at the higher end of the range of values might have been larger but for the position of the VR2 fixed receivers at the extremes of the array (potentially limiting detection of the 
extremities of movement). Plus, the presence of Powick and Diglis weirs blocked at least some of the fish from moving further upstream and so being able to further increase their range. It was also apparent that fish that had been captured by electric fishing had a significantly larger total (home) range than those captured by angling $(6112 \pm 2075 \mathrm{~m}$ versus $2739 \pm 1229 \mathrm{~m})$. This result is consistent with Alós et al. (2012), who hypothesised that angler-captured fish are often have small home ranges and thus have low-activity phenotypes.

In summary, the tracking of these 18 non-indigenous $B$. barbus over a 12 month period revealed strong patterns in river residence, consistent patterns in net movements that related to the pre-spawning movements and the negative consequences of river impoundment for their movements. As many westflowing British rivers have been heavily modified with engineering structures, this engineering could be limiting these non-indigenous $B$. barbus from dispersing into new areas of river, although this might be overcome if, for example, anglers intentionally move fish around the structures. Similar to studies in the $B$. barbus indigenous range, there was high variability in the total range of these tagged non-indigenous fish. These data on total range also suggested a continuum of individual movements that were strongly influenced by their vulnerability to angler capture, indicating that in movement studies on fishes, the sampling method can strongly affect the data on individual behaviour.

Acknowledgements We thank Pete Reading, Shaun Nurse and Martin Cullen for their assistance with capturing barbel by angling, and Alan Henshaw of Calverton Fish Farm for help in electric fishing. We are also grateful to the Severn River Trust and Barbel Society for funding the work, and the Environment Agency for logistical support.

Open Access This article is distributed under the terms of the Creative Commons Attribution 4.0 International License (http:// creativecommons.org/licenses/by/4.0/), which permits unrestricted use, distribution, and reproduction in any medium, provided you give appropriate credit to the original author(s) and the source, provide a link to the Creative Commons license, and indicate if changes were made.

\section{References}

Acolas, M., C. Le Pichon \& E. Rochard, 2017. Spring habitat use by stocked one year old European sturgeon Acipenser sturio in the freshwater-oligohaline area of the Gironde estuary. Estuarine, Coastal and Shelf Science 196: 58-69.

Alós, J., M. Palmer \& R. Arlinghaus, 2012. Consistent selection towards low activity phenotypes when catchability depends on encounters among human predators and fish. PloS ONE 7: e48030.

Antognazza, C. M., D. Andreou, S. Zaccara \& J. R. Britton, 2016. Loss of genetic integrity and biological invasions result from stocking and introductions of Barbus barbus: insights from rivers in England. Ecology and Evolution 6: 3439 .

Baras, E., 1995a. Seasonal activities of Barbus barbus - Effect of temperature on time-budgeting. Journal of Fish Biology 46: 806-818.

Baras, E., 1995b. Thermal related variations of seasonal and daily spawning periodicity in Barbus barbus. Journal of Fish Biology 46: 915-917.

Baras, E., 1996. Selection of residence area and non-reproductive homing in a shoaling freshwater teleost, the barbel Barbus barbus (L). Underwater Biotelemetry, Proccedings of the 1st Conference and Workshop on Fish Telemetry in Europe. E. Baras \& JC Philippart (eds). University of Liege. Belgium. pp. 47-58.

Baras, E., 1997. Environmental determinants of residence area selection by Barbus barbus in the River Ourthe. Aquatic Living Resources 10: 195-206.

Baras, E. \& J. Philippart, 1989. Application of radio tracking to the study of behavioural ecology of barbel (Barbus barbus (L.)). Problems, strategies and first results. Cahiers d'Ethologie Appliquee (Belgium).

Baras, E. \& B. Cherry, 1990. Seasonal activities of female barbel Barbus barbus (L.) in the River Ourthe (Southern Belgium), as revealed by radio tracking. Aquatic Living Resources 3: 283-294.

Baras, E., H. Lambert \& J. C. Philippart, 1994. A comprehensive assessment of the failure of Barbus barbus spawning migrations through a fish pass in the canalized River Meuse (Belgium). Aquatic Living Resources 7: 181-189.

Bašić, T. \& J. R. Britton, 2016. Characterizing the trophic niches of stocked and resident cyprinid fishes: consistency in partitioning over time, space and body sizes. Ecology and Evolution 6: 5093-5104.

Beechie, T., E. Beamer \& L. Wasserman, 1994. Estimating coho salmon rearing habitat and smolt production losses in a large river basin, and implications for habitat restoration. North American Journal of Fisheries Management 14: 797-811.

Birnie-Gauvin, K., K. Aarestrup, T. M. O. Riis, N. Jepsen \& A. Koed, 2017. Shining a light on the loss of rheophilic fish habitat in lowland rivers as a forgotten consequence of barriers, and its implications for management. Marine and Freshwater Ecosystems, Aquatic Conservation: 1-5.

Britton, J. R. \& J. Pegg, 2011. Ecology of European Barbel Barbus barbus: implications for river, fishery, and conservation management. Reviews in Fisheries Science 19: 321-330.

Britton, J. R. \& R. E. Gozlan, 2013. How many founders for a biological invasion? Predicting introduction outcomes from propagule pressure. Ecology 94: 2558-2566. 
Britton, J. R., I. G. Cowx \& G. Peirson, 2004. Sources of error in the ageing of stocked cyprinids. Fisheries Management and Ecology 11: 415-417.

Buddendorf, W. B., I. A. Malcolm, J. Geris, M. E. Wilkinson \& C. Soulsby, 2017. Metrics to assess how longitudinal channel network connectivity and in-stream Atlantic salmon habitats are impacted by hydropower regulation. Hydrological Processes 31: 2132-2142.

Bunt, C. M., 2001. Fishway entrance modifications enhance fish attraction. Fisheries Management and Ecology 8: 95-105.

Campbell, H. A., M. E. Watts, R. G. Dwyer \& C. E. Franklin, 2012. V-Track: software for analysing and visualising animal movement from acoustic telemetry detections. Marine and Freshwater Research 63: 815-820.

Capra, H., H. Pella \& M. Ovidio, 2018. Individual movements, home ranges and habitat use by native rheophilic cyprinids and non-native catfish in a large regulated river. Fisheries Management and Ecology 25: 136-149.

Carosi, A., L. Ghetti, G. La Porta \& M. Lorenzoni, 2017. Ecological effects of the European barbel Barbus barbus (L., 1758) (Cyprinidae) invasion on native barbel populations in the Tiber River basin (Italy). The European Zoological Journal 84: 420-435.

Centre for Ecology \& Hydrology, 2017. https://nrfa.ceh.ac.uk/ about-data [online] National River Flow Archive accessed on 10 November 2017.

Cowx, I. G., 1994. Stocking strategies. Fisheries Management and Ecology 1: 15-30.

Crooks, J. A., 2005. Lag times and exotic species: the ecology and management of biological invasions in slow-motion. Ecoscience 12: 316-329.

Crooks, J. A. \& M. E. Soulé, 1999. Lag times in population explosions of invasive species: causes and implications. Kluwer Academic Publishers, Dordrecht: 103-125.

Fausch, K. D., 2007. Introduction, establishment and effects of non-native salmonids: considering the risk of rainbow trout invasion in the United Kingdom. Journal of Fish Biology 71: $1-32$.

Freyhof, J. \& E. Brook, 2011. European red list of freshwater fishes. Publications Office of the European Union, Luxembourg.

Gutmann Roberts, C. \& J. R. Britton, 2018. Quantifying trophic interactions and niche sizes of juvenile fishes in an invaded riverine cyprinid fish community. Ecology of Freshwater Fish 27: 976-987.

Harrison, A., A. Pinder, \& C. Gutmann Roberts, 2017. River Teme fisheries habitat walkover: Barbel Society Final Report. Bournemouth Univeristy Global Environmental Solutions (BUG).

Hunt, P. C. \& J. W. Jones, 1974. A population study of Barbus barbus (L.) in the River Severn, England Movements. Journal of Fish Biology 6: 269-278.

Knudson, C., 2017. An Introduction to Model-Fitting with the R package glmm.

Lucas, M. C., 2000. The influence of environmental factors on movements of lowland-river fish in the Yorkshire Ouse system. The Science of the Total Environment 251: 223-232.

Lucas, M. C. \& E. Batley, 1996. Seasonal movements and behaviour of adult barbel Barbus barbus, a riverine cyprinid fish: implications for river management. Journal of Applied Ecology 33: 1345-1358.

Lucas, M. C. \& P. A. Frear, 1997. Effects of a flow-gauging weir on the migratory behaviour of adult barbel, a river cyprinid. Journal of Fish Biology 50: 382-396.

Lucas, M. \& E. Baras, 2001. Migration of freshwater fishes. Wiley, Malden.

Mitamura, H., K. Uchda, Y. Miyamoto, T. Kakihara, A. Miyagi, Y. Kawabata, K. Ichikawa \& N. Arai, 2012. Short-range homing in a site-specific fish: search and directed movements. Journal of Experimental Biology 215: 2751-2759.

Mouton, A. M., M. Schneider, J. Depestele, P. L. M. Goethals \& N. De Pauw, 2007. Fish habitat modelling as a tool for river management. Ecological Engineering 29: 305-315.

Ovidio, M. \& J. C. Philippart, 2002. The impact of small physical obstacles on upstream movements of six species of fish. Hydrobiologia 483: 55-69.

Ovidio, M., D. Parkinson, J. C. Philippart \& E. Baras, 2007. Multiyear homing and fidelity to residence areas by individual barbel (Barbus barbus). Belgium Journal of Zoology 137: $183-190$.

Pelz, G. \& A. Kästle, 1989. Ortsbewegungen der barbe Barbus barbus (L.): radiotelemetrische standortbestimmungen in der Nidda (Frankfurt/Main). Fischökologie 1: 15-28.

Penaz, M., V. Barus, M. Prokes \& M. Homolka, 2002. Movements of barbel, Barbus barbus (Pisces: Cyprinidae). Folia Zoologica 51: 55-66.

Pinder, A. C., D. Andreou, E. Hardouin, S. Sana, P. Gillingham, P. \& C. Gutmann Roberts, 2016. Spawning success and population structure of shad (Alosa spp.) in the River Teme, 2015: with supplementary notes on sea lamprey spawning. BUG Report to Natural England.

R Core Team, 2017. R: a language and environment for statistical computing. R Core Team, Vienna.

Radinger, J. \& C. Wolter, 2014. Patterns and predictors of fish dispersal in rivers. Fish and Fisheries 15: 456-473.

Trapletti, A., K. Hornik, B. LeBaron \& M. K. Hornik, 2017. Package 'tseries'.

Vemco, 2017. V9 Coded Transmitters. https://vemco.com/wpcontent/uploads/2014/02/v9-coded.pdf. Last accessed 27/03/2018.

Vilizzi, L., G. H. Copp, M. G. Carter \& M. Penaz, 2006. Movement and abundance of barbel, Barbus barbus, in a mesotrophic chalk stream in England. Folia Zoologica 55: 183-197.

Wheeler, A. \& D. R. Jordan, 1990. The status of the barbel, Barbus barbus (L.) (Teleostie, Cyprinidae) in the United Kingdom. Journal of Fish Biology 37: 393-399.

Ziv, G., E. Baran, S. Nam, I. Rodriguez-Iturbe \& S. A. Levin, 2012. Trading-off fish biodiversity, food security, and hydropower in the Mekong River Basin. Proceedings of the National Academy of Sciences of the United States of America 109: 5609-5614. 